\title{
IMPROVEMENT OF INVESTMENT SUPPORT FOR HUMAN CAPITAL DEVELOPMENT IN THE CONDITIONS OF DIGITAL TRANSFORMATION
}

\author{
INNA IRTYSHCHEVA, ANTONINA TRUSHLYAKOVA
}

\begin{abstract}
The features of investment in the development of human capital in Ukraine at the regional level, in the private sector and at the household level have been investigated. It is noted that the state acts as the main investor in the formation and development of human capital, financing the main expenses in the field of education, medicine, cultural and physical development and social security. However, state policy in the context of limited financial resources and their irrational use does not contribute to the effective development and reproduction of human potential in accordance with the needs of the digital economy. Despite the nominal increase in social spending, their structure is irrational, and the spending itself do not consider as investment. An insufficient level of investment activity in the field of investment in human capital observe at the corporate and individual levels. It has been determined that the main incentive for the development of human capital affects the formation of a motivational basis at all levels is the purposeful, consistent and pragmatic activity of state authorities aimed at implementing a certain development strategy for the country, ensuring its security and macroeconomic stability. An important condition is also the creation of a regulatory framework that is adapted to the specifics and realities of economic and social transformations in the context of digitalization, the regulation of labor relations, and the preservation of social and investment guarantees. To regulate and intensify investment activities, a model of investment support for the human capital development is proposed. It involves the redistribution of investment resources in accordance with the subjects of investment and the expected results of the investment process, forms and criteria for assessing individual components of human capital at different stages of the life cycle, together form a general model of financing it development and reproduction at all levels.
\end{abstract}

Keywords: investments, investment support, human capital, digital transformation, digitalization. JEL Classification: J24, J41, O15.

\section{INTRODUCTION}

Human capital is one of the key factors in ensuring economic growth and competitiveness of the national economy. Ensuring the effective development and use of human capital in the national economy in the context of digitalization requires the development of an investment strategy aimed at meeting the economy needs in the human capital development and its continuous reproduction on a 
new qualitative basis, with appropriate adaptive abilities to new challenges in a transformational environment.

Human capital is the most significant component in the digital economy development; it acts as the driving force behind transformation processes, the main source of competitive advantages and determines the main vector of socio-economic transformations that meet the development trends of the global market. Based on this, the concept of improving the mechanisms for the national transport and logistics system development requires additional research.

\section{Literature RevieW, Generalization of Main Statements}

The formation and accumulation of human capital requires large material and other costs from the state, enterprises and citizens. This applies to both education and other areas of its formation. Such costs can be estimated only partially, but even such an approximate estimate indicates that the value of accumulated human capital exceeds the size of material accumulation, and the rate of intangible accumulation determines the rate of economic growth of the country [1].

World experience has proven that investment in human capital is the main core, forms a multiplier effect for the knowledge economy development and contributes to progressive transformations of socio-economic systems on the way to a new technological order.

As noted by O. Hizelo, "A characteristic feature of investing in human capital is that a person is not only an object of investment, but also its purpose. So, the development and expansion of educational, intellectual, informational, organizational, managerial, motivational resources, the view of a person as the main, determining and qualitatively inexhaustible factor of growth of a new type, as well as the goal of this growth, is a distinctive feature of our time" [2, p. 12].

Thus, it is investment in human capital in the context of implementing the strategy for sustainable development of the national economy and society in the context of digitalization that is the main generator of progress in this direction and one of the defining conditions for effective adaptation of human development to changes. At the same time, today in economic thought there is no consensus on the definition of the investment concept in human capital, which explains by certain features, including:

- intangible nature of investments depends on the investment object, its natural abilities, skills and self-motivation;

- invisibility of investments from their object, that is, the object of investments, unlike material and financial resources, cannot belong to the subject of investments;

- ability of the investment object (by which we mean human capital) in self-investment;

- specificity of the investment cycle, conventionally divided into the stages of the life cycle of human capital and requires investments of various forms and content;

- complexity of assessing the future value of investments, largely depends on the personality, natural abilities, character, temperament of carriers of human capital, their motives of behavior, etc.;

- return on investment is determined by the remaining until the end of the working period of a person's life;

- severity of determining the economic and social feasibility of capital investments in a person, because not all such investments can lead to the expected effect.

In classical economic theory, investment in human capital is defined as "any action that enhances the skills and abilities of workers and, thereby, labor productivity. That is, in economic essence, these are costs that contribute to productivity growth, since unit costs are carried out with the expectation that these costs will be many times offset by a growing income stream in the future "[3]. This approach, in our opinion, is rather narrow and determines exclusively the corporate essence of investment in human capital.

Scientists V. Lysak and V. Semendyak adhere to the positions that characterize investments in the context of each individual carrier of human capital. They refer to investments in human capital as any measures taken to increase labor productivity, namely: "expenses for health care, for obtaining general 
and special education; costs associated with finding a job, professional training at the enterprise, migration, the birth and upbringing of children, the search for an economically significant message on prices and earnings" [4, p. 550].

Z. Pichkurova understands investment in human capital as "all types of tangible and intangible investments, expressed in monetary or non-monetary form. It has a positive impact on its qualitative and quantitative structure, lead to an increase in the level of income of its carriers, contribute to the growth of labor productivity, increase national income, an increase in the level of economic development of the country and, ultimately - an increase in the level of national competitiveness of the country" [5].

In turn, O. Nosyk in addition to material and financial costs includes the costs of an individual's lifetime and those of his income that he did not receive, spending time, efforts and funds on the formation and accumulation of human capital into the investment in human capital. Therefore, the lost benefits of an individual associated with his activities aimed at the formation and accumulation of human capital are investments in the latter [6].

Therefore, under investment in human capital we will consider resources (material, financial, informational), invested both directly in the development of individual carriers of human potential and in the conditions necessary for the labor development, intellectual, social and other components of capital, the use of which will allow get a certain economic and social effect in the future.

The purpose of the article is to analyze the current state of investment in human capital and substantiate the directions for improving investment support for its development in the context of digital transformations.

\section{DiscUSSION}

In essence, investments in human capital are investments in intangible assets that accumulate and develop intangible resources for the productive activity of people, namely: knowledge, competencies, experience, health, social skills, intellectual and entrepreneurial abilities. Accordingly, depending on the investment purpose, the following components of human capital distinguish:

- physical capital (health, endurance, physical strength, psychological stability);

- labor capital - a set of professional knowledge, skills and competencies that allow productively and efficiently perform a certain type of work in accordance with the position held;

- cultural capital - linguistic and cultural competences of a person, functioning in the form of a system of values, knowledge and ideas that legitimize status and power and contribute to maintaining the established social order;

- intellectual capital - intellectual abilities, skills and abilities that allow you to form new knowledge, innovative ideas and translate them into an innovative product, technology or service. In the context of the digital economy development, the intellectual capital is the main asset creates competitive advantages and contributes to high-quality transformational transformations;

- entrepreneurial capital is a combination of a person's entrepreneurial abilities (analytical thinking, sociability and communication, organizational skills, etc.) that contribute to the organization of effective production, operational, commercial, social and any other activity.

Each of the listed components (or their specific combination) of human capital can be an object of investment, and their clear definition allows to systematize the criteria for assessing investment returns, possible payback periods and directions of influence on economic processes. In particular, as noted above, one of the most important investment objects in the context of digitalization is precisely the development of intellectual capital, in combination with excellent physical and labor (professional) potential, can significantly accelerate innovation processes and increase the population adaptability level in the face of changes.

An important factor in the formation of an effective investment strategy for the human capital development is the disaggregation of investment entities. Subjects of investment in the human capital 
development can be divided into 4 levels, each of which has specific motivational characteristics, goals and a corresponding set of sources for attracting investment resources (Fig. 1).

Each of the listed entities contributes to the formation and development of human capital within the available resources and in accordance with the set strategic goals. At the same time, in our opinion, the level of investment activity in the field of financing the human capital development depends primarily on the created conditions that determine the riskiness of these investments and stimulating factors that contribute (or do not contribute) to the choice (all other things being equal) human capital as the investment object. That is, the role of the state, in our opinion, should not be limited exclusively to the distribution of budgetary funds between the main areas of social security and legal regulation of the development and reform of education, health care, culture and sports, social security, as well as create incentives to enhance investment in human capital at all specified levels.

We agree with the opinion of T. Panchyshyn that "The initial task of the state is to create favorable conditions for the disclosure of human potential, its motivation. It is necessary to significantly improve the image of scientists. The state should become an integrator of human potential, gather the best people, improve the training system and advanced personnel training, creating all the necessary conditions for them to achieve their specific goal. Ukraine will be able to establish itself in the development of a globalized world only if there is an appropriate national intelligence, education and science" [7, p. 103].

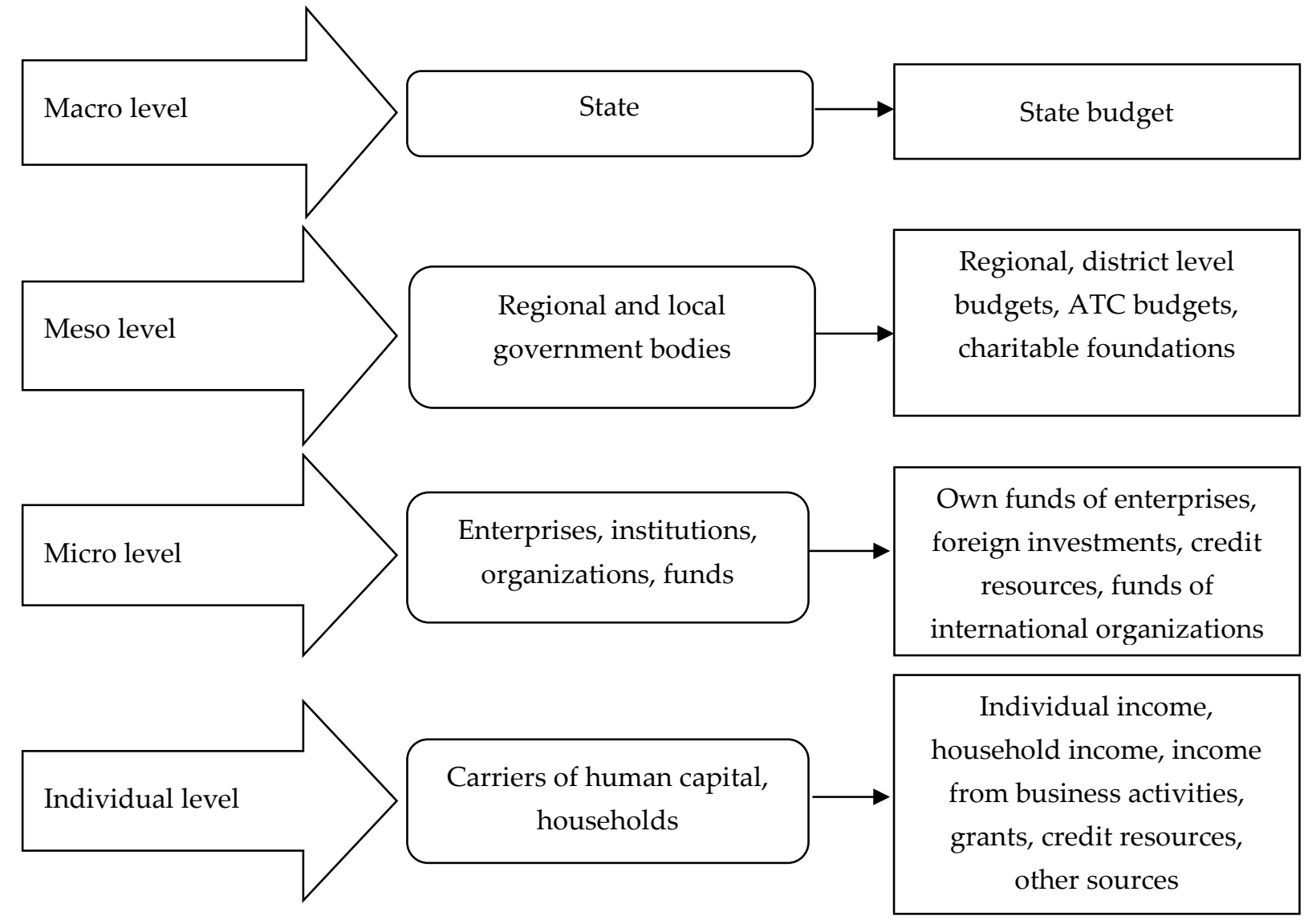

Fig. 1. Model of investment support for human capital development [Systematized by the authors].

The main stimulus for the human capital development that affects the formation of a motivational basis at all levels is the purposeful, consistent and pragmatic activity of state authorities aimed at implementing a specific development strategy for the country, ensuring its security and macroeconomic stability. An important condition is also the creation of a regulatory framework that is adapted to the specifics and realities of economic and social transformations in the context of digitalization, the regulation of labor relations, and the preservation of social and investment guarantees. 
At the meso level, important motivational factors for the intensification of investment in human capital is the effective implementation of the decentralization reform. According to its results, it is expected an increase in the revenue side of the local budgets and an increase in the powers of local selfgovernment bodies to allocate budget resources in accordance with the problems and strategic needs of the population and the development of territories.

At the micro level, the volume of investment in human capital largely depends on the system of taxation and accounting for personnel costs operating in the country, the availability of state benefits, compensation and legal guarantees for investment protection, state policy for the development of the labor market, etc.

The main incentives for individual investment in the development of one's own potential are clearly defined prospects for its implementation, created conditions for unhindered access to information and technology, a high standard of living, that is, the availability of savings that can be invested in one's own development.

In Ukraine, compared to most developed countries, investment in human capital is not in top priority. The dynamics and structure of financing social expenditures from the state and regional budgets, the structure of household expenditures and the volume of expenditures of enterprises in the corporate sector can this confirm. Table 1 shows the structural and dynamic changes in expenditures from the state budget for the human capital development.

\begin{tabular}{|c|c|c|c|c|c|}
\hline Period & Health Care & $\begin{array}{c}\text { Physical and } \\
\text { spiritual } \\
\text { development }\end{array}$ & Education & $\begin{array}{c}\text { Social security } \\
\text { and social } \\
\text { security }\end{array}$ & $\begin{array}{c}\text { Total } \\
\text { expenditures }\end{array}$ \\
\hline 2015 & 11450,4 & 6619,2 & 30185,7 & 103700,9 & 576911,4 \\
\hline$\%$ & 1,9 & 1,1 & 5,2 & 17,9 & 100 \\
\hline 2016 & 12456,3 & 4958,9 & 34825,4 & 151965,5 & 684743,4 \\
\hline$\%$ & 1,2 & 0,7 & 5,3 & 22,19 & 100 \\
\hline 2017 & 16729,1 & 7898,1 & 41140,2 & 144478,3 & 839243,7 \\
\hline$\%$ & 1,99 & 0,94 & 4,9 & 17,2 & 100 \\
\hline 2018 & 22617,9 & 10107,1 & 44323,4 & 163865,6 & 985842 \\
\hline$\%$ & 2,29 & 1,03 & 4,5 & 16,62 & 100 \\
\hline 2019 & 38561,6 & 9967 & 51657,1 & 218628,6 & 1072892 \\
\hline$\%$ & 3,59 & 0,93 & 4,81 & 20,38 & 100 \\
\hline Growth 2019/2015, \% & 236,7 & 50,5 & 71,1 & 110,8 & 85,9 \\
\hline Structural changes, \% & 1,69 & $-0,17$ & $-0,39$ & 2,48 & 0 \\
\hline
\end{tabular}

Tab. 1. Social expenditures from the state budget of Ukraine by functional classification, million UAH. Source: Compiled according to the Ministry of Finance of Ukraine [8].

During the period 2015-2019, the volume of expenditures from the state budget increased by $85.9 \%$, which is primarily due to the significant devaluation of the national currency during this period. In the structure of expenditures, in general, it considers as an investment in human capital, the largest share (20.38\%) in 2019 spent on social protection and social security, including direct-targeted assistance to the population below the poverty line, subsidizing utilities, covering part of the obligations of the pension fund, and the like. During the research period, the share of this group of expenses increased by $2.48 \%$. Considering the structure of expenditures in the context of human capital development in the context of digitalization, we believe that an increase in the share of social security expenditures in the budget is a negative phenomenon and indicates an increase in poverty among citizens. The received social benefits do not direct to the human capital development; only to maintain vital activity at a minimum level. For effective social security, the state must create conditions for providing citizens with jobs and ensuring a decent level of wages. 
Analyzing other items of expenditure, it can be stated that during 2015-2019, the most significant increase in expenditures on health care $(+236.7 \%)$, and their share of total expenditures - by $1.69 \%$ compared to 2015. This growth considers as positive, if budgetary resources use effectively.

Expenditures on education in the context of the digital economy development consider by fundamental investments, create the basis for the formation and adaptation of human capital, and, according to the logic of strategic transformations, should grow in the future. The analysis showed that over the past 5 years, despite a slight nominal growth $(+50 \%)$, the share of spending on education tends to decline. This is primarily associated with educational reform, with the aim of optimizing the number of educational institutions and reengineering curricula, thereby contributing to a reduction in the number of employees in the industry and other costs. In our opinion, in the modern conditions of the digital technologies development, reforms in education are necessary to adapt the knowledge obtained in educational institutions with the main trends in science and technology, culture and other areas. However, the cost reduction does not allow for qualitative transformations, since funding, first, for the development of the material and technical base in schools is being reduced, the number of paid services is growing, and the number of teachers, hours allocated for classes, the volume of materials provided, etc. The reduction in the volume of budgetary funding for higher and secondary technical education is a negative trend, since it limits access to knowledge and obtaining qualifications required in the digital environment for a significant part of graduates.

The structure and dynamics of spending on education indicates that the state, despite the introduction of certain reforms in the educational sphere, continues to consider education as an element of social policy and not as an investment in human capital.

Reducing the cost of spiritual development and culture, as well as insufficiently efficient allocation of these resources also creates obstacles for the effective development of human potential.

Analyzing social spending at the local and regional budgets level it should note that its share is higher than at the central level by an average of 3-8\%, depending on the direction of financing. This is primarily due to the gradual implementation of the decentralization reform, according to which part of the financial authority to invest in human capital, including education and medicine, transfer to lower levels in accordance with the principle of subsidiarity.

The team of authors identified "the government's priority task now is to improve the administration system of public investments in the direction of increasing the efficiency of capital investments and their use in accordance with the priority areas of the state strategic development. This may ensure the rational use of earmarked funds, reduce bureaucratic barriers that hinder the implementation of projects, increase the transparency of procedures selection of investment projects and prevention of corruption. These measures will create an additional basis for the effective development of national investment potential" [11].

\section{CONCLUSIONS}

Thus, research of the human capital main trends and investment directions in Ukraine showed that it is precisely the prevalence of a passive investment strategy for the human capital development, in which the volumes and directions of investment were determined mainly on the basis of a past trends comparison and the financial capabilities of the state regarding the coverage of social costs. Its weak connection with the strategic objectives of the structural restructuring of the national economy in the context of the digital technologies development led to a decrease in the level of human potential and an increase in structural, regional, professional and social imbalances.

An important factor in the human capital development is the stimulation of investment in education from the private sector. It requires the development of effective mechanisms for financial cooperation between the corporate sector and higher education institutions, the creation of appropriate programs to encourage business. This should include the following: tax incentives, the possibility of joint formation of educational programs for students of certain specialties or selective financing by private enterprises of additional programs (for instance, language courses, programming), provision of 
government guarantees for investment in education, etc. The formation of a private market for digital education, licensing simplification of such institutions and activation of public-private and municipalprivate partnership projects in this area will also contribute to improving the investment climate.

\section{REFERENCES}

[1] Krayevs'kyy V.M. Investment in human capital - a prerequisite for economic growth of the country. Investytsiyi: praktyka ta dosvid, 5 (2011), 7-9. (in Ukrainian)

[2] Giselo O.I. Investment in Human Capital as a Condition for Social Development of Ukraine. Labor market and employment, 1 (2015), 11-14. (in Ukrainian)

[3] Makkonnell K.R., Bryu S.L. Economics: principles, problems and politics. INFRA-M, Moscow, 2009.

[4] Lysak V.Yu., Semendyak V.M. Human capital development: however, problems and prospects. Global and national economic problems, 1 (2018), 548-552. (in Ukrainian)

[5] Pichkurova Z. Investments in human capital as a determining factor in ensuring the competitiveness of the national economy. Formation of market relations in Ukraine, 6 (157) (2014), 229-233. (in Ukrainian)

[6] Nosyk O. Investments in human capital: the main peculiarities and factors of choice. Economic Theory and Law, 1 (20) (2015), 120-129. (in Ukrainian)

[7] Panchyshyn T. Investing in human capital - the key to modernizing Ukraine's economy. Scientific Bulletin of Uzhhorod University. Series "Economics",1 (49) (2017), 99-104. (in Ukrainian)

[8] Official website of the Ministry of Finance of Ukraine: Expenditures of the state budget of Ukraine. Available at: https://index.minfin.com.ua. (in Ukrainian)

[9] Irtyshcheva I., Kramarenko I., Shults S., Boiko Ye., Blishchuk K., Hryshyna N., Popadynets N., Dubynska I., Ishchenko O., Krapyvina D. Building favorable investment climate for economic development. Accounting, 6 (5) (2020), 773-780.

[10] Irtyshcheva I., Kramarenko I., Shults S., Stegney M., Blishchuk K., Boiko Ye., Popadynetsc N., Samotiy N., Rogatina L., Hryshyna N. An economic management system for sustainable development in black sea region. Accounting, 6 (4) (2020), 387-394.

[11] Kramarenko I., Irtyshcheva I., Senkevich O., Topchiy O., Voit D. Structural-dynamic characteristics of investment resources of the regions. Efektyvna ekonomika, 3 (2020). Available at: http://www.economy.nayka.com.ua/pdf/3_2020/82.pdf (in Ukrainian)

Address: Inna Irtyshcheva, Antonina Trushlyakova, Admiral Makarov National University of Shipbuilding, 9 Geroyiv Stalingrada St., Mykolaiv, 54025 Ukraine.

E-mail: innauamd@gmail.com, antonina.trushliakova@gmail.com

Received: September 09, 2020; revised: October 18, 2020.

Іртищева Інна, Трушлякова Антоніана. Удосконалення інвестиційного забезпечення розвитку дюдського капіталу в умовах цифрових трансформацій. Журнал Прикарпатського університету імені Василя Стефаника, 7 (3) (2020), 89-96.

Досліджено особливості інвестування у розвиток дюдського капіталу в Україні на державному, регіональному рівні, у приватному секторі та на рівні домогосподарств. Зазначено, що основним інвестором процесів формування та розвитку дюдського капіталу виступає держава, що фінансує основні витрати у сфері освіти, медицини, культурного і фізичного розвитку та соціального 
забезпечення. Проте, державна політика в умовах обмеженості фінансових ресурсів та їх нераціонального використання не сприяе ефективному розвитку та відтворенню дюдського потенціалу у відповідності до потреб цифрової економіки. Попри номінальне збільшення соціальних витрат, їх структура є нераціональною, а самі витрати не розглядаються у якості інвестицій. Недостатній рівень інвестиційної активності у сфері інвестицій у людський капітал спостерігається також на корпоративному та індивідуальному рівнях. Визначено, що основним стимулом розвитку людського капіталу, що впливає на формування мотиваційного базису всіх рівнів є цілеспрямована, послідовна та прагматична діяльність держаних органів влади, спрямована на реалізацію визначеної стратегії розвитку країни, забезпечення іiі безпеки та макроекономічної стабільності. Важливою умовою є також створення нормативно-правової бази, що адаптована до особливостей та реалій економічних і соціальних трансформацій в умовах діджиталізації, унормування трудових відносин, збереження соціальних та інвестиційних гарантій. Для урегулювання та активізації інвестиційної діяльності запропоновано модель інвестиційного забезпечення розвитку дюдського капіталу, що передбачає перерозподіл інвестиційних ресурсів у відповідності до суб'єктів інвестування та очікуваних результатів інвестиційного процесу, форм і критеріїв оцінки окремих складових людського капіталу на різних етапах життєвого циклу, що в сукупності формують загальну модель фінансування його розвитку і відтворення на всіх рівнях.

Кдючові слова: інвестиції, інвестиційне забезпечення, людський капітал, цифрова трансформація, діджиталізація. 